\title{
Breve semblanza de la Historia del Arte en México
}

\author{
Dra. Beatriz de la Fuente
}

Dedicada a estudiantes extranjeros

Al comienzo me preocupé de que el escultor registrara la belleza sucesiva de un ser que está cambiando; después el arte se convirtió en una

especie de operación mágica capaz de evocar un rostro perdido.

Marguerite Yourcenar, Memorias de Adriano: (153).

j

Cómo evocar los rostros perdidos a través de magia del arte? Inicio con esta reflexión, pues una de las principales labores de la Historia del Arte, desde su existencia como disciplina, ha sido desentrañar el significado de las formas para estudiar las manifestaciones artísticas de distintas épocas.

En esta búsqueda por conocer a los hombres a través de sus creaciones, las obras de arte han sido objeto de su estudio. A través de ellas enfrenta al hombre a sus circunstancias vitales, dialoga con las imágenes que narra el acontecer de tiempos $y$ espacios lejanos $y$ presentes; descubre la faz y la mirada de quienes han desaparecido y su necesidad de explicarse desde la expresividad misma de tales obras.

En la creación, voz de los imaginarios, habita aquello que somos sin serlo. El arte, espejo de las formas transformadas es testigo del cambio $y$ las semejanzas, de lo múltiple y lo común, de lo propio y lo compartido; del olvido que aún permanece.
En las obras percibimos a los hombres que transmutan en materia para ser descubiertos como carne. En ellas se define la expresión de los pueblos la aprehensión o comprensión de las experiencias, la construcción de una realidad que se sabe cambiante.

Depósito de historias y encuentros, el arte revela la madeja confusa e impenetrable del tiempo para mostrar los rostros que nos conforman. En las obras se desvanecen los límites de la historia $y$ en su lugar aparece el diálogo, la posibilidad de encuentro, las formas en su labor de enseñarnos quienes somos.

No es tarea fácil desempañar su significado para hacer explícito el mensaje que, a pesar de las distancias, se proponen desvelar aquellas imágenes indefinidas que buscan identificarse.

Frente a nosotros, ese espejo que implican las obras, aguarda en quietud impaciente. Su ser a veces opaco, otras traslúcido y muy pocas transparente poco a poco revela el mensaje, la verdad de la obra que es la verdad de los creadores.

"Investigadora Emérita de la UNAM, del Instituto de Investigaciones Estéticas. 


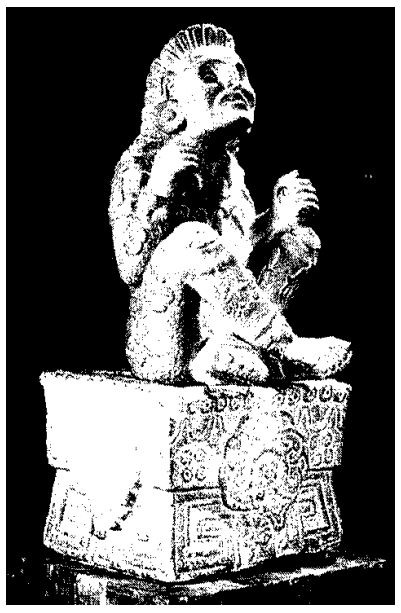

mural, la cerámica, la orfebrería, entre otros; los artistas del México antiguo dejaron evidencia de su entendimiento y vivencia de la realidad, de su realidad.

El arte prehispánico conjuga varios estilos, varias maneras de expresión. Es un arte que se hace más que de semejanzas, un arte que expresa conceptos, pensamientos e ideales apoyados en la observación y su consecuente explicación del mundo.

Recordemos, entre tantas más, la unicidad de las cabezas colosales olmecas, la monumental arquitectura de Teotihuacan, la maestría de las pinturas murales de Bonampak, la severa arquitectura funeraria de Monte Albán, las poderosas esculturas de los mexicas, las modestas terracotras del Occidente y la eterna sonrisa de las figurillas de barro de Veracruz; son unas pocas ya que es imposible mencionar otras por que no viene a cuento. La producción artística prehispánica, que a la fecha se conoce, es enorme.

Sabemos que en ellas se guardan los secretos de un pasado que es posible reconstruir y comprender. En los espacios, las líneas, el color y la textura de cada una de las obras, laten los impulsos de una historia que permanece en la materia $y$ revive para ser recordada, conocida $e$ interpretada.
Dicha tradición artística mesoamericana enfrenta un modo distinto de entender $y$ representar la realidad de raíz de la conquista. Aquel mosaico complejo que caracterizó a las culturas precolombinas, sufre un cambio, el cambio que implica la presencia del "otro" que se infiltra para nombrar y definir el curso de una historia iniciada tiempo atrás.

El antiguo modo de percibir y representar la realidad, se mira bajo el tamiz de lo profano. Ahora las imágenes deben sustituirse, los lugares sagrados reemplazarse, el pensamiento ha de tomar otro cauce.

Los monasterios suplen el lugar del ceremonial antiguo. Las capillas abiertas son ahora el sitio de culto. Claustros y capillas posas completan el nuevo lenguaje.

Ahora se representan historias no conocidas, personajes nuevos protagonizan las composiciones, nuevos dioses con nuevos atributos $y$ cualidades.

La intención del arte es diferente. El olvido pretende cubrir las formas pasadas para dar paso a las presentes. Sin embargo, la consolidación del nuevo ser que se propone como "verdadero", la propuesta de occidente y la fe del cristianismo sobre la herejía, se fundan sobre una tradición que no es fácil dejar de lado.

Así, el arte del siglo xvi en México es un arte mestizo, ecléctico. Un arte que concilia las reminiscencias del pasado indígena con el arte y el pensamiento de occidente. Y ahí están las obras, testimonio del recuerdo y de la novedad, de la tradición y el cambio de lo propio y de lo ajeno. Ejemplo de la síntesis y la asimilación, de la búsqueda de permanencia y las innovaciones. Ahí están las formas compartidas, la expresión de un arte que legitima, consolida, alberga y recrea el tránsito doloroso o grato de los procesos.

La historia continúa y con ella la necesidad de crear $y$ de transformar la experiencia del mun- 


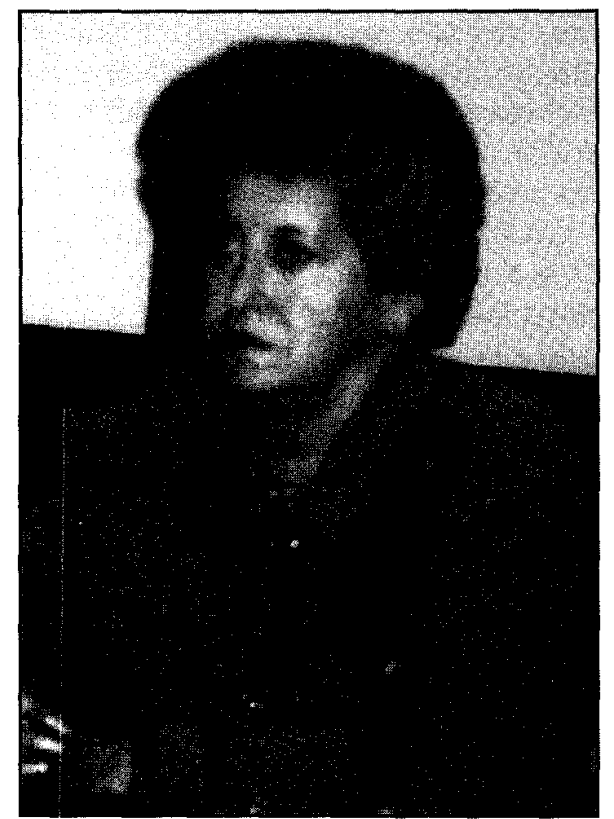

Beatriz de la Fuente

do en imágenes. Así el arte del primer encuentro, aquellas manifestaciones didácticas y sencillas del siglo XvI, se transforman para dar paso al barroco novohispano.

Influenciado por las tendencias europeas, con el matiz y el carácter del mestizaje, el barroco de la época colonial adquirió características peculiares y propias. La fusión de razas, no solamente de la española $y$ la indígena, sino de la africana $y$ hasta de la oriental, trajo como consecuencia una complejidad tal que "toda esta movilidad hirviendo dentro de un mundo... contribuyera a hacer del alma de las Indias algo extraño $y$ peregrino en los anales del espíritu humano. ${ }^{2}$

Las inquietudes científicas, intelectuales y religiosas que definen estos siglos de la colonia, aunados a la multiplicidad de razas, dieron paso a un estilo artístico complejo, basado en la diversidad y en la exuberancia de las formas.

Los ejemplos no se atienen a las características de un solo estilo, podríamos hablar de varios. Producto de este carácter polivalente son, entre otros, Santa María Tonantzintla en Puebla, cuyas características difieren de obras como el Altar del Perdón o el Altar de los Reyes en la catedral Metropolitana.

La flexibilidad y permeabilidad del barroco desemboca en la consolidación de una sociedad única y distinta cuya complejidad respira aires de independencia.

Tres siglos de colonización encuentran su fin a principios del siglo XIX. Para la historia, este periodo implica una búsqueda de estabilidad y presencia ante los ojos del mundo. México, alejado del dominio de la corona española, inicia su camino hacia la libertad y la propuesta de su unicidad y solidez como nación.

El pasado prehispánico cobra vida. Se convierte en el portavoz de una legitimación que busca solidez en lo propio, en las raíces olvidadas, en el sojuzgado eco de los antepasados.

La mirada hacia el interior, el afán por dar a conocer la historia milenaria que funda la identidad presente, compartió fuerza con la preocupación por estar a la vanguardia en relación a las propuestas del Viejo Continente.

El arte del siglo XIX se debate entre las formas académicas que se estilaban en Europa y los temas nacionalistas. Se trata de un arte de formas puristas y estilizadas, propias de la academia, que retrata la idealización de un pasado en el que se pretende encontrar la raíz de la identidad.

Así llegamos al siglo xx, siglo que se inicia con la Revolución. Aquel recuerdo idealizado, esa legi-

\footnotetext{
${ }^{2}$ Irving A. Leonard, La época barroca en el México Colonial, México, Fondo de Cultura Económica, 1990: 65.
} 


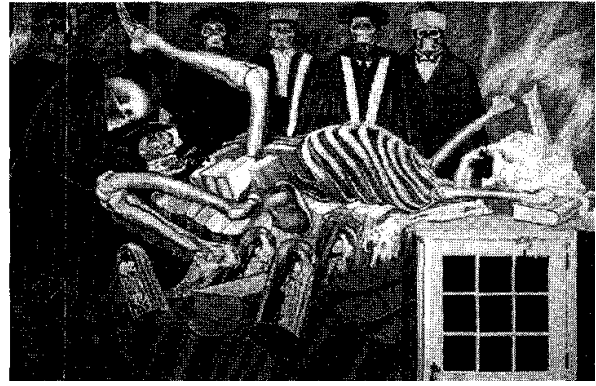

Mural Civilización americana (Los dioses del mundo moderno), de José Clemente Orozco

timación en el pasado prehispánico, la constante búsqueda de mostrar un país pleno y abundante, cae ante el llamado abrumador de las carencias $y$ el olvido de las clases poco privilegiadas.

Durante el siglo xx se evocó un pasado para legitimar un presente cuya realidad se desconocía. Con la Revolución surge la conciencia ante un presente basado en la desigualdad, un presente que se muestra a través del arte con el muralismo.

Los muralistas, además de buscar una identidad artística propia, se unen al llamado revolucionario. Obras de gran formato, figuras expresivas, colores intensos desdoblan un lenguaje que además de reforzar los ideales de la revolución, se manifiesta como un estilo propio.

Se olvida el arte purista de las academias y se inicia una búsqueda a través de técnicas y géneros artísticos que propongan la identidad de un arte mexicano único y diferente.

Contemporáneos a los muralistas, otros artistas incursionaron en temas comprometidos con la identidad nacional aunque no comulgaron por completo con las ideas revolucionarias. La obra de dichos artistas muestra la asimilación, adaptación e interpretación de las vanguardias europeas a la voluntad artística mexicana.

En nuestro breve recorrido por la historia del arte mexicano, pocos ejemplos nos han servido para comprender a las obras como promotoras del ser y devenir de la historia. Hemos visto cómo traducen en imágenes el padecimiento y la experiencia de los aconteceres.

En este caso la transformación, propuesta y voluntad del arte mexicano, se narran en la diversidad $y$ vastedad de sus formas. Desde las figurillas de barro hasta las construcciones modernas. La historia del arte busca el sentido e identidad de las múltiples voces que nos definen. A través de las formas muestra la complejidad y polivalencia de una producción artística que cruza, renueva y mezcla sus discursos.

El encuentro con las formas libera a los rostros perdidos del aliento de las épocas y de los obstáculos del tiempo y del espacio. Así, la magia del arte habla para asegurarnos de que no hay un solo camino para conocer nuestra verdad histórica.

El conocimiento del arte nos lleva a comprender que somos hilos de un anudado origen que se despliega, se enreda y se confunde. Que somos presente que añora, recuerda y se nombra en el pasado. Somos presente incierto, expectante e inquieto, presente que busca ser futuro.

Las obras permanecen para recordarnos que somos tiempos entre el recuerdo y la expectativa. Tiempos simbióticos. Historias concéntricas, cómplices e impuras, que fluyen, se encuentran, conviven y se legitiman en el rostro de la creación.

Los momentos y monumentos radicales en la historia del arte mexicano deben ser compartidos con personas de otras latitudes, de otros pueblos, de modo tal que se extienda su interés y se afinque la identidad nacional 
